\title{
Chicken manure as an organic fertilizer ${ }^{1}$
}

\author{
Miguel A. Muñoz,"z Octavio Colbergs and José A. Dumas"
}

\begin{abstract}
Four chicken manure samples (two fresh, one two months old and the other 24 months old) were evaluated for $\mathrm{pH}$, total and available nutrient content, and total and exchangeable Al. Total $\mathrm{N}$ ranged from 2.47 to $3.72 \%$, the lowest value corresponding to the 24-month-old manure. There was little variation among manures as to total $P, C a$ and $K$, averaging $18,588,18,358$ and $24,238 \mathrm{p} / \mathrm{m}$, respectively. Total $\mathrm{Mg}$ and total Al were higher in the 2-and 24-month-old manures; however, no increase in the exchangeable fractions of these cations was observed. Exchangeable $\mathrm{Ca}$ ranged from 1,558 to $5,200 \mathrm{p} / \mathrm{m}$; however, no specific pattern with age of the manure was observed. All the $K$ present in the manures was in the exchangeable form. Available $P$ increased with age of the manure. This $P$ fraction represented 10, 7, 68 and $97 \%$ of total $P$ for fresh (1), fresh (2), 2-month-old, and 24-month-old manures, respectively.
\end{abstract}

\section{RESUMEN}

La gallinaza como abono orgánico

Se analizó el contenido de nutrimentos totales y disponibles, el Al total e intercambiable y el $\mathrm{pH}$ de cuatro muestras de gallinaza, (dos frescas y dos de 2 y 24 meses). El contenido total de $\mathbf{N}$ en la gallinaza de 24 meses fue de $2.47 \%$; sin embargo, en la gallinaza fresca y en la de 2 meses sobrepasó el $3 \%$. El contenido total de $\mathrm{Mg}$ y Al fue mayor en la gallinaza de 2 y 24 meses, pero no hubo aumento en las fracciones intercambiables de estos dos cationes. Todo el $K$ presente en la gallinaza se encuentra en forma intercambiable. Se observó un aumento significativo en el $P$ disponible en la gallinaza de $\mathbf{2}$ y $\mathbf{2 4}$ meses al compararla con las dos muestras frescas. Esta fracción de $\mathrm{P}$ representó un valor medio de $9 \%$ del $\mathrm{P}$ total en la gallinaza fresca, $67 \%$ en la de dos meses y $\mathbf{9 7 \%}$ en la de $\mathbf{2 4}$ meses. El $\mathrm{Ca}$ intercambiable fluctuó entre 1,558 y $5,200 \mathrm{p} / \mathrm{m}$ y el $\mathrm{Mg}$ entre 750 y $1,863 \mathrm{p} / \mathrm{m}$. No se observó ninguna relación entre la fracción intercambiable (disponible) de estos elementos y la edad del material.

\section{INTRODUCTION}

In Puerto Rico, chicken manure is an agricultural waste that could be of great importance as an organic fertilizer $(3,8)$. The Department of Agriculture of Puerto Rico reports an average yearly population of 8.2 million chickens which yield approximately 71,500 metric tons of manure every year (3). The progressive accumulation of this material represents an environmental hazard, leading to significant pollution of waterways and lakes $(4,6)$. Furthermore, the transport and deposit of the manure

'Manuscript submitted to Editorial Board 18 October 1989.

'Assistant Researcher, Department of Agronomy and Soil.

${ }^{3}$ Research Assistant, Department of Horticulture.

${ }^{4}$ Research Assistant, Central Analytical Laboratory. 
by rivers and streams diminishes the useful life of lakes and water reservoirs.

The Puerto Rico Environmental Quality Board allows commercial chicken growers to dispose temporarily of the manure by burying it in trenches. However, chicken growers are charged with the responsibility of finding a safe practical way to permanently dispose of the material. Its use as organic fertilizer offers a promising alternative to the problem.

In order to develop recommendations for the use of chicken manure as organic fertilizer, there is a dire need for reliable information on its nutrient content. It is also necessary to determine the fraction of the total nutrient content that is available to a crop during its growing season. The study herein reported was conducted to evaluate the nutrient content of chicken manure and determine possible changes with age of the material.

\section{MATERIALS AND METHODS}

Chicken manure samples were collected from four different locations in the Coamo area (south-central region of Puerto Rico) and analyzed for total and available nutrients, total and exchangeable $\mathrm{Al}$, and $\mathrm{pH}$. Two of the manures were fresh and the other two were taken from trenches where they had been aging for 2 and 24 months. Chicken farmers use coffee hulls and rice hulls as bedding materials. The 24-month-old manure contained coffee hulls, whereas the other three manures contained rice hulls.

Total nutrients were analyzed by the wet ashing method (7). Nitrogen and phosphorus were determined colorimetrically with a Technicon II Autoanalyzer. Nitrogen was determined by the Kjeldahl method. Calcium, magnesium and aluminum were determined by atomic absorption, and potassium by atomic emission with a Perkin Elmer 2380 AAS. ${ }^{5}$

The $\mathrm{pH}$ was measured in a 1:2 chicken manure:water ratio, with an Orion Research Model 701 A/Digital pH meter. Exchangeable cations $\left(\mathrm{Ca}^{+2}, \mathrm{~K}^{+}, \mathrm{Mg}^{+2}\right)$ were extracted with $1 \mathrm{~N}$ ammonium acetate $(\mathrm{pH} 7)$ and exchangeable $\mathrm{Al}$ with $1 \mathrm{~N} \mathrm{KCl}(7)$. Available $\mathrm{P}$ on samples with $\mathrm{pH}$ below 7 was determined by the Bray II method; on samples with $\mathrm{pH}$ above 7, by the Olsen method.

Total nutrient content of coffee hulls and rice hulls was also determined. Three samples of each material were analyzed by the wet ashing method. Two of the coffee hull samples consisted of parchment and skin, and the third one only of parchment. Rice hull samples differed in their composting degree, aging 0,2 and 6 months.

iTrade names in this publication are used only to provide specific information. Mention of a trade name does not constitute a warranty of equipment or materials by the Agricultural Experiment Station of the University of Puerto Rico, nor is this mention a statement of preference over other equipment or materials. 


\section{RESULTS AND DISCUSSION}

The chicken manure that had been buried in a trench for 24 months changed markedly in color and texture. The material was dark with a compost-like appearance, contrary to the brownish, sand-like appearance of the fresh and 2-month-old manures (fig. 1). The composting of the material was not uniform within the trench. Layers of composted manure were found above and below other layers with lesser degrees of decomposition. Apparently, low moisture content in the manure at the time it was placed in the trench delayed the composting process.

Total nutrient analysis indicated a nitrogen content ranging from 2.47 to $3.72 \%$, the lowest value corresponding to the oldest chicken manure (24 months) (table 1). Nitrogen content as determined by both methods, wet ashing and Kjeldahl distillation, was similar. The range of nitrogen content agreed with values reported in the United States for chicken manure $(2,8,10)$. The decrease in nitrogen content of the 24-month-old manure may be the result of ammonia volatilization and nitrate losses by leaching. However, $\mathrm{Mg}$ and $\mathrm{Al}$ were higher in the older material. Reasons for the increase in $\mathrm{Al}$ and $\mathrm{Mg}$ may be differences in the chemical composition of the bedding material (coffee vs rice hulls) and the slower dissolution and loss of $\mathrm{Al}$ - and $\mathrm{Mg}$-containing compounds present in the manure.

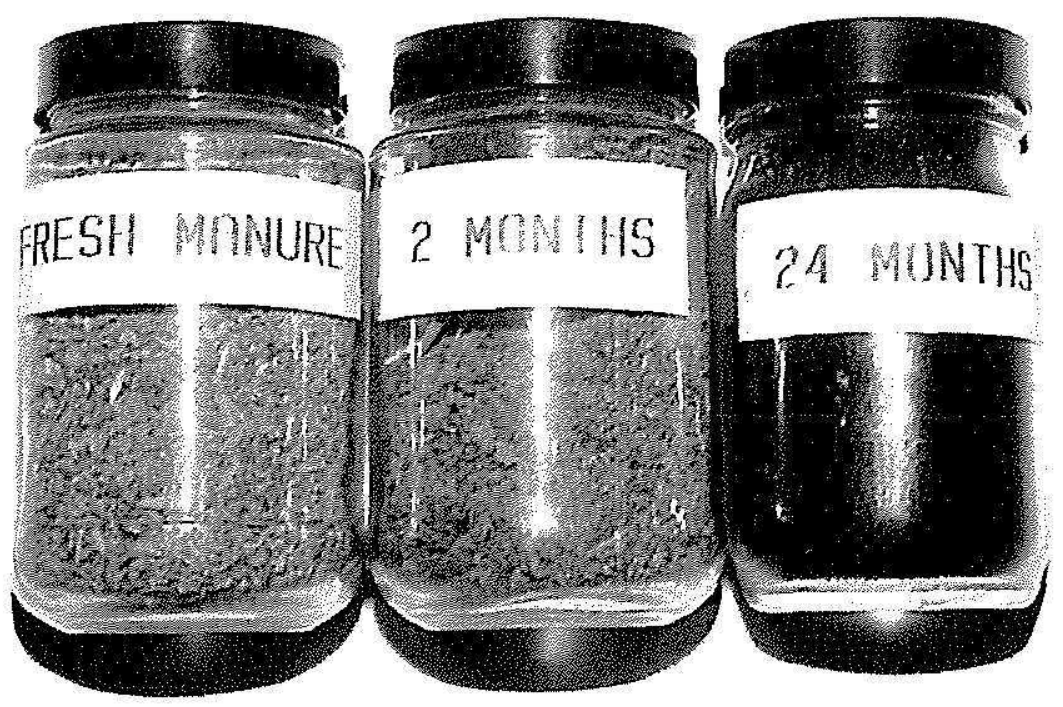

FiG. 1.-Changes in color and texture of chicken manure as a result of aging. 
TABLE 1.-Total nutrient content of chicken manure (wet ashing)

\begin{tabular}{lcccccc}
\hline & $N$ & P & K & Ca & Mg & Al \\
Manure Sample & $\%$ & - & & & \\
\hline Fresh (1) & 3.72 & 18,900 & 20,350 & 27,100 & 4,910 & 2,200 \\
Fresh (2) & 3.44 & 17,700 & 16,383 & 22,350 & 5,383 & 3,500 \\
2-month-old & 3.57 & 19,500 & 19,800 & 29,300 & 5,940 & 7,700 \\
24-month-old & 2.47 & 18,250 & 16,900 & 19,000 & 7,700 & 12,900 \\
\hline
\end{tabular}

The 24-month-old manure contained coffee hulls, whereas the most recent manure contained rice hulls. Coffee is grown in soils where exchangeable $\mathrm{Al}$ is usually high (1), a condition which results in accumulation of this element in the plant tissue. Chemical analysis of the bedding material indicated higher nutrient and Al content in coffee hulls than in rice hulls (table 2 ). The $\mathrm{Al}$ content of coffee hulls was twice the amount present in the fresh and 2-month-old rice hulls. However, the Al content of the 6-month-old composted rice hulls was higher than the Al content of parchment + skin coffee hulls. Apparently, during the composting process, $\mathrm{Al}$ - and $\mathrm{Mg}$-containing compounds are more resistant to dissolution or decomposition. This resistance results in a net gain per unit mass of these two elements. It is also possible that during the composting process $\mathrm{Al}$ chelates are formed, a condition which contributes to the slower dissolution.

Sharp differences in nutrient content were also observed between parchment + skin and parchment coffee hulls. The skins seemed to be richer in $\mathrm{N}, \mathrm{P}$ and $\mathrm{K}$ than the parchment. The former contained approximately $1.5,3$ and 5 times more $\mathrm{N}, \mathrm{P}, \mathrm{K}$ respectively than the parchment (table 2).

The $\mathrm{pH}$ decreased with increasing age of the manure. The $\mathrm{pH}$ of the two fresh manures was above 7 , whereas the 2-and 24-month-old manure showed $\mathrm{pH}$ values of 6.45 and 6.37 , respectively. The production of $\mathrm{H}^{+}$ during mineralization and nitrification processes may be responsible for

TABLE 2.-Total nutrient content of coffee hulls and rice hulls

\begin{tabular}{lrrrrrr}
\hline Sample & $\mathrm{N}$ & $\mathrm{P}$ & $\mathrm{K}$ & $\mathrm{Ca}$ & $\mathrm{Mg}$ & $\mathrm{Al}$ \\
\hline Coffee & $\%$ & \multicolumn{1}{c}{ P/m } & & & & \\
$\quad$ Parchment & & & & & & \\
$\quad$ Parchment + skin (1) & 1.52 & 1,600 & 27,200 & 4,800 & 1,000 & 124 \\
$\quad$ Parchment + skin (2) & 1.69 & 1,750 & 30,650 & 4,550 & 1,200 & 99 \\
Rice & & & & & & \\
$\quad$ Fresh & 0.33 & 450 & 1,700 & 700 & 300 & 50 \\
2-month-old & 0.36 & 600 & 2,000 & 700 & 400 & 53 \\
6-month-old & 0.56 & 400 & 1,200 & 900 & 600 & 133 \\
\hline
\end{tabular}


TABLE 3.-Exchangeable cations, available $P$, total $N$ (Kjeldahl method), and $p H$ of chicken manure

\begin{tabular}{lccrrrrr}
\hline Manure Sample & $\mathrm{pH}$ & $\mathrm{N}$ & $\mathrm{P}$ & $\mathrm{K}$ & $\mathrm{Ca}$ & $\mathrm{Mg}$ & $\mathrm{Al}$ \\
\hline Fresh (1) & 7.47 & 4.07 & 1,876 & 20,550 & 3,575 & 1,238 & N.D.' \\
Fresh (2) & 7.57 & 3.20 & 1,310 & 16,358 & 1,558 & 750 & N.D. \\
2-month-old & 6.45 & 3.90 & 13,230 & 19,375 & 5,200 & 1,863 & N.D. \\
24-month-old & 6.37 & 2.32 & 17,400 & 16,350 & 3,025 & 1,543 & N.D. \\
\hline
\end{tabular}

'Not detectable.

the lower $\mathrm{pH}$ values observed (5). Available $\mathrm{P}$ increased in the 2- and 24 -month-old manures reaching values of 68 and $97 \%$ of total $P$, respectively. In the two fresh manures available $P$ represented only 10 and $7 \%$ of total P (table 3, fig. 1). The results indicate that most of the P present in the manure will be available to a crop during a growing season of 3 to 4 months. Almost all $\mathrm{K}$ present in the manures is in the exchangeable form, with values ranging from 97 to $100 \%$ of total $\mathrm{K}$ (fig. 2). Exchangeable Ca ranged from 7 to $18 \%$ and exchangeable $\mathrm{Mg}$ from 14 to $25 \%$ of their respective totals. However, we observed no specific pattern with age of the material.

The results indicate that chicken manure can be an excellent source of $\mathrm{N}, \mathrm{P}$, and $\mathrm{K}$ and, to a minor extent, can supply $\mathrm{Ca}$ and $\mathrm{Mg}$ to crops.

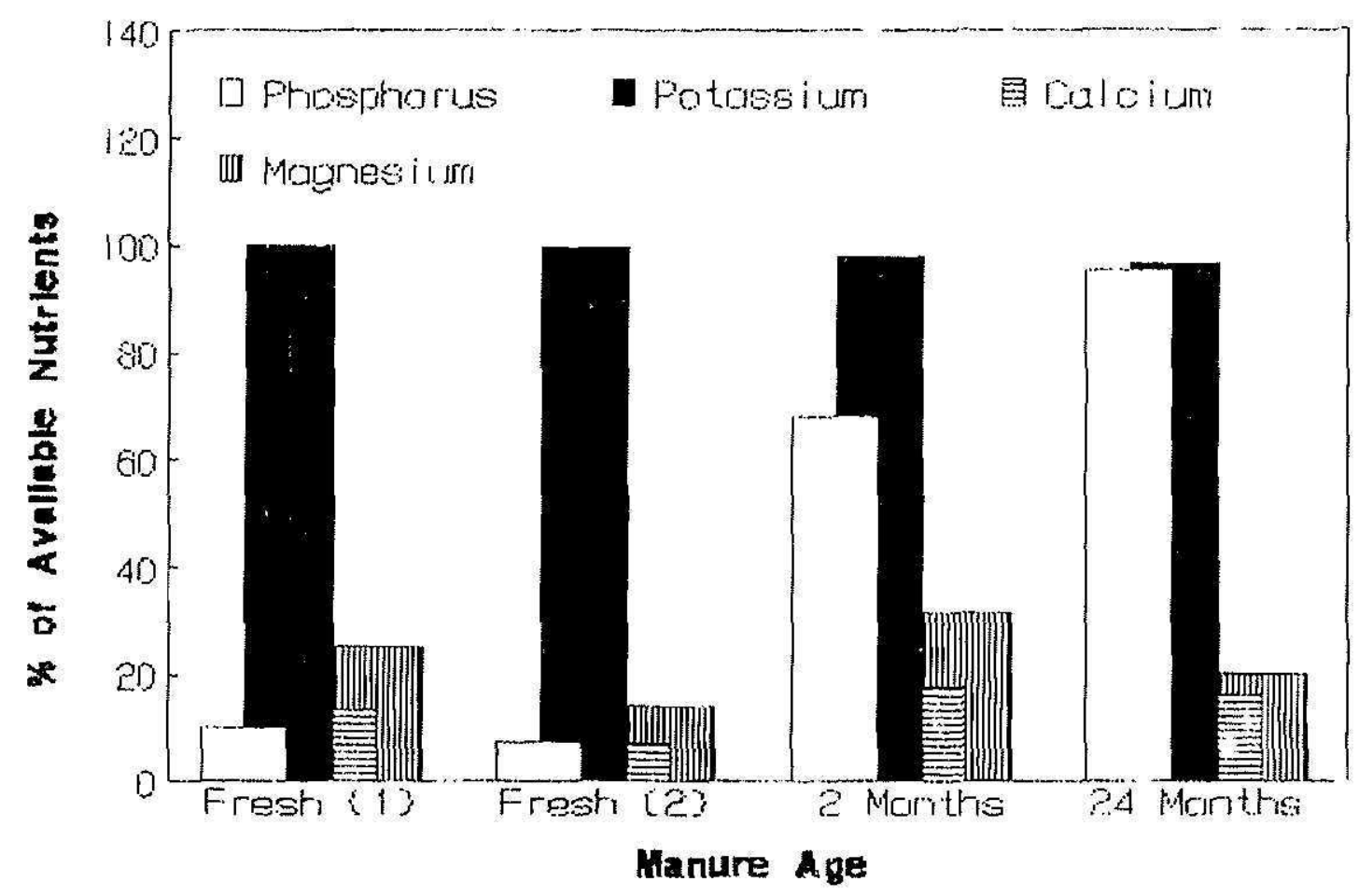

FIG. 2.-Percentage of total nutrients in chicken manure considered available to crops based on recommended soil tests. 
The composting process decreases $\mathrm{pH}$ and nitrogen content, but increases $\mathrm{P}$ availability. Since the $\mathrm{pH}$ of the manure is close to or above neutrality, the material will be beneficial in acid soils. Further research is necessary to clarify relative increase or decrease in nutrient content of the manure as the material ages, to fractionate nitrogen content $\left(\mathrm{NH}_{4}{ }^{+}, \mathrm{NO}_{3}{ }^{-}\right)$, and to evaluate the effect of manure applications on soil chemical and physical properties.

\section{LITERATURE CITED}

1. Abruña, F., J. Vicente-Chandler and S. Silva, 1959. The effect of different fertility levels on yields of intensively managed coffee in Puerto Rico. J. Agric. Univ. P. R. 43 (3): $141-46$.

2. Bitzer, C. C. and J. T. Sims, 1988. Estimating the availability of nitrogen in poultry manure through laboratory and field studies. J. Environ. Qual. 17: 47-54.

3. Departamento de Agricultura, Estado Libre Asociado de Puerto Rico. Anuario de Estadísticas Agrícolas de Puerto Rico, 1985-1986.

4. Environmental Quality Board, 1984-1985. Goals and progress of statewide quality management planning, Puerto Rico. Commonwealth of Puerto Rico, Office of the Governor.

5. Hauck, R. D., 1984. Significance of nitrogen fertilizer microsites reactions in soil. pp. 507-20. In R. D. Hauck et al. (ed) Nitrogen in Crop Production. Am. Soc. Agro., Madison, Wisconsin.

6. Liebhardt, W. C., C. Golt and J. Tupin, 1979. Nitrate and ammonium concentration of ground water resulting from poultry manure applications. J. Environ. Qual. 8:21115.

7. Page, A. L., R. H. Miller and D. R. Kenney, 1982. Methods of Soil Analysis, Part 2: Chemical and Microbiological Properties. 2nd ed. Am. Soc. Agro., Madison, Wiscon$\sin$.

8. Perkins, H. F., M. B. Parker and M. E. Walker, 1964. Poultry manure; its composition and use as fertilizer. Georgia Agric. Exp. Stn. Bull. NS-123.

9. Sims, J. T., 1986. Nitrogen transformations in a poultry amended soil: temperature and moisture effects. J. Environ. Qual. 15: 59-63.

10. —, 1987. Agronomic evaluation of poultry manure as a nitrogen source for conventional and no-tillage corn. Agron. J. 79: 563-70. 